\title{
Exogenous melatonin enhances salt secretion from salt glands by upregulating the expression of ion transporter and vesicle transport genes in Limonium bicolor
}

\author{
Junpeng Li ${ }^{\dagger}$, Fang Yuan ${ }^{\dagger}$, Yanlu Liư ${ }^{\dagger}$ Mingjing Zhang, Yun Liu, Yang Zhao, Baoshan Wang ${ }^{*}$ and Min Chen ${ }^{*}$
}

\begin{abstract}
Background: Salt, a common environmental stress factor, inhibits plant growth and reduces yields. Melatonin is a pleiotropic molecule that regulates plant growth and can alleviate environmental stress in plants. All previous research on this topic has focused on the use of melatonin to improve the relatively low salt tolerance of glycophytes by promoting growth and enhancing antioxidant ability. It is unclear whether exogenous melatonin can increase the salt tolerance of halophytes, particularly recretohalophytes, by enhancing salt secretion from the salt glands.

Results: To examine the mechanisms of melatonin-mediated salt tolerance, we explored the effects of exogenous applications of melatonin on the secretion of salt from the salt glands of Limonium bicolor (a kind of recretohalophyte) seedlings and on the expression of associated genes. A pretreatment with $5 \mu \mathrm{M}$ melatonin significantly improved the growth of L. bicolor seedlings under $300 \mathrm{mM} \mathrm{NaCl}$. Furthermore, exogenous melatonin significantly increased the dry weight and endogenous melatonin content of L. bicolor. In addition, this treatment reduced the content of $\mathrm{Na}^{+}$and $\mathrm{Cl}^{-}$in leaves, but increased the $\mathrm{K}^{+}$content. Both the salt secretion rate of the salt glands and the expression level of genes encoding ion transporters ( $L b H T K 1, \angle b S O S 1, \angle b P M A$, and LbNHX1) and vesicular transport proteins (LbVAMP721, LbVAP27, and LbVAMP12) were significantly increased by exogenous melatonin treatment. These results indicate that melatonin improves the salt tolerance of the recretohalophyte $L$. bicolor via the upregulation of salt secretion by the salt glands.
\end{abstract}

Conclusions: Our results showed that melatonin can upregulate the expression of genes encoding ion transporters and vesicle transport proteins to enhance salt secretion from the salt glands. Combining the results of the current study with previous research, we formulated a novel mechanism by which melatonin increases salt secretion in $L$. bicolor. Ions in mesophyll cells are transported to the salt glands through ion transporters located at the plasma membrane. After the ions enter the salt glands, they are transported to the collecting chamber adjacent to the secretory pore through vesicle transport and ions transporter and then are secreted from the secretory pore of salt glands, which maintain ionic homeostasis in the cells and alleviate $\mathrm{NaCl}$-induced growth inhibition.

Keywords: Ion homeostasis, Limonium bicolor, Melatonin, Salt gland, Salt secretion

\footnotetext{
*Correspondence: bswang@sdnu.edu.cn; chenminrundong@126.com

${ }^{\dagger}$ Junpeng Li, Fang Yuan and Yanlu Liu contributed equally to this work.

Shandong Provincial Key Laboratory of Plant Stress, College of Life Science,

Shandong Normal University, 88 Wenhua East Road, Jinan 250014, P.R. China
}

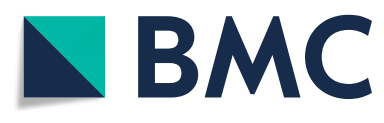

(c) The Author(s). 2020 Open Access This article is licensed under a Creative Commons Attribution 4.0 International License, which permits use, sharing, adaptation, distribution and reproduction in any medium or format, as long as you give appropriate credit to the original author(s) and the source, provide a link to the Creative Commons licence, and indicate if changes were made. The images or other third party material in this article are included in the article's Creative Commons licence, unless indicated otherwise in a credit line to the material. If material is not included in the article's Creative Commons licence and your intended use is not permitted by statutory regulation or exceeds the permitted use, you will need to obtain permission directly from the copyright holder. To view a copy of this licence, visit http://creativecommons.org/licenses/by/4.0/ The Creative Commons Public Domain Dedication waiver (http://creativecommons.org/publicdomain/zero/1.0/) applies to the data made available in this article, unless otherwise stated in a credit line to the data. 


\section{Background}

Plants are challenged by various biotic and abiotic stresses throughout their growth and development [1-3]. Salt stress is a ubiquitous abiotic environmental stress that negatively affects plants by inducing first osmotic stress and then ionic stress and oxidative stress, resulting in growth retardation, yield losses, and plant death [4-7].

Salt-tolerant plants called halophytes have evolved a variety of mechanisms that allow them to meet this challenge and limit the adverse effects of salt on their metabolism [8]. One type of halophyte, the recretohalophytes, secrete excess salt from salt glands or salt bladders located mainly on their leaves, thereby ensuring a lower $\mathrm{Na}^{+}$content in their shoots and avoiding the excessive accumulation of ions in their cells, which protects against salt-associated damage $[9,10]$.

Although salt glands play a key role in the salt tolerance of plants, the mechanism of salt secretion is unclear. Three mechanisms have been proposed to explain this process: an osmotic mechanism [11], exocytosis [12-14], and transfer systems similar to fluid flow in animals [15]. Yuan et al. [9] proposed that membranebound translocating proteins such as plasma membrane (PM) $\mathrm{H}^{+}$-ATPase (PMA) and the $\mathrm{Na}^{+} / \mathrm{H}^{+}$antiporter (SOS1, salt overly sensitive) participate in the salt secretion process. PMA produces a $\mathrm{H}^{+}$electrochemical potential gradient that drives the $\mathrm{Na}^{+} / \mathrm{H}^{+}$antiporter to expel excess $\mathrm{Na}^{+}$from the cells, which could cause newly acquired ions to enter the salt gland $[16,17]$. Ding et al. [17] showed that salt secretion from the salt glands of Limonium bicolor, a typical recretohalophyte with a 16-cell salt gland, may be an ion-active transport process, in which PMA and SOS1 play a coordinated role. The increased salt secretion function in the recretohalophyte Avicennia marina is accompanied by the upregulated expression of genes encoding PMA, SOS1, NHX1 (tonoplast $\mathrm{Na}^{+} / \mathrm{H}^{+}$antiporter 1), and vacuolar $\mathrm{H}^{+}$-ATPase subunit c (VHA-c1) [18]. Tan et al. [19] used an immunoblot analysis to demonstrate that the protein levels of PMA and NHX1 significantly increased as the rate of salt secretion increased. An RNAsequencing (RNA-seq) study revealed that the candidate genes encoding membrane-bound ion translocating proteins were associated with the salt secretion function of the salt gland in the recretohalophyte Reaumuria trigyna [20]. In the recretohalophyte Mesembryanthemum crystallinum $\mathrm{L}$., the increased $\mathrm{NHX}$ and $\mathrm{H}^{+}$-ATPase $(\mathrm{V}$ ATPase) activity of the vacuoles increased the $\mathrm{Na}^{+}$content in the salt bladder [21]. These results indicate that ion transporters play an important role during salt gland secretion.

There is also substantial evidence supporting the role of vesicle transport in salt gland secretion [9]. In Limonium Mill., many small transport vesicles were observed in the secretory cells of the salt glands [12, 22, 23], suggesting that these vesicles may participate in salt gland secretion. Thomson and Liu [24] treated Tamarix aphylla with rubidium and observed that the resulting electron-dense region was concentrated in small vesicles. A large number of small vesicles are present in the salt glands of L. bicolor, typically fusing with the PM [22]. When L. bicolor leaves were treated with brefeldin A, a vesicle secretion inhibitor, the secretion rate of the salt glands was severely inhibited [22]. Similarly, Flowers et al. [25] reported results that supported the hypothesis that vesicle transport plays a key role in salt gland secretion, although they also indicated that transporters may be simultaneously involved. Vesicle transport consumes less energy than transport proteins, and ions can accumulate to a high concentration in the vesicles [26]. Recently, LbSYP61 (syntaxin from plants 61, a vesicle transport protein) was shown to directly regulate salt secretion levels from the salt glands of the recretohalophyte L. bicolor [26].

Many factors influence salt secretion; for example, both the salt secretion ability and the density of salt glands of Glaux maritima L. increased under salt stress [27]. The secretion ability of $L$. bicolor salt glands was promoted by $\mathrm{Ca}^{2+}$ and $\mathrm{K}^{+}$under salt stress [17], whereas the stress-induced accumulation of $\mathrm{K}^{+}$in L. bicolor salt gland cells (mainly in the nucleus and cytoplasm) increased their salt secretion ability [22]. The detailed mechanisms underlying these changes in secretion are not clear, however.

Melatonin (N-acetyl-5-methoxy-tryptamine) was first discovered in plants in 1995 [28, 29], and has since been identified in a wide variety of plant species. Over the past few years, many functions of melatonin have been revealed in different plant tissues and biological processes [30-32]. Melatonin regulates plant growth and development [33-35], and plays an important role in plant resistance to stresses, especially salt stress [31], drought stress [36], cold stress [37], oxidation stress [38, 39], and nutrient deficiencies [40]. The melatonin content increases in plants under stress, improving the plant's ability to adapt to these challenges [41].

Melatonin-related regulatory mechanisms have been reported in some studies [42], but more research is needed on the regulation and function of melatonin in plant stress tolerance. All previous research on this topic has focused on the use of melatonin to improve the relatively low salt tolerance of glycophytes by promoting growth and enhancing antioxidant ability [7]. It is unclear whether exogenous melatonin can increase the salt tolerance of halophytes, particularly recretohalophytes, by enhancing salt secretion from the salt glands. If exogenous melatonin increases the salt-secreting ability of recretohalophytes, whether it is by regulating the ion 
transporters and vesicular transport proteins. With its high salt tolerance and ornamental and medicinal value, L. bicolor is a typical pioneer plant that grows on saline alkali land and has a wide planting range [9]. In this study, we examined the effects of melatonin on the salt tolerance of L. bicolor, in an effort to elucidate the molecular mechanisms involved in its salt secretion.

\section{Results}

Melatonin alleviates the $\mathrm{NaCl}$-induced growth inhibition of $L$. bicolor seedlings

The growth of $L$. bicolor seedlings was significantly inhibited by a $300 \mathrm{mM} \mathrm{NaCl}$ treatment; compared with the control $(0 \mathrm{mM} \mathrm{NaCl})$, the salt-treated seedlings had significantly lower dry weights (Fig. 1). Exogenous melatonin $(5 \mu \mathrm{M})$ significantly promoted seedling growth, with treated seedlings reaching a greater biomass than the controls, both under the 0 or $300 \mathrm{mM} \mathrm{NaCl}$ treatments. Exogenous melatonin increased the shoot dry weight of the seedlings exposed to $0 \mathrm{mM} \mathrm{NaCl}$ by $17.33 \%$, whereas it increased the dry weight of the salttreated seedlings by $20.9 \%$.

\section{Melatonin significantly increases the number of salt glands}

The $300 \mathrm{mM} \mathrm{NaCl}$ treatment significantly increased the density of salt glands produced on the L. bicolor leaves,

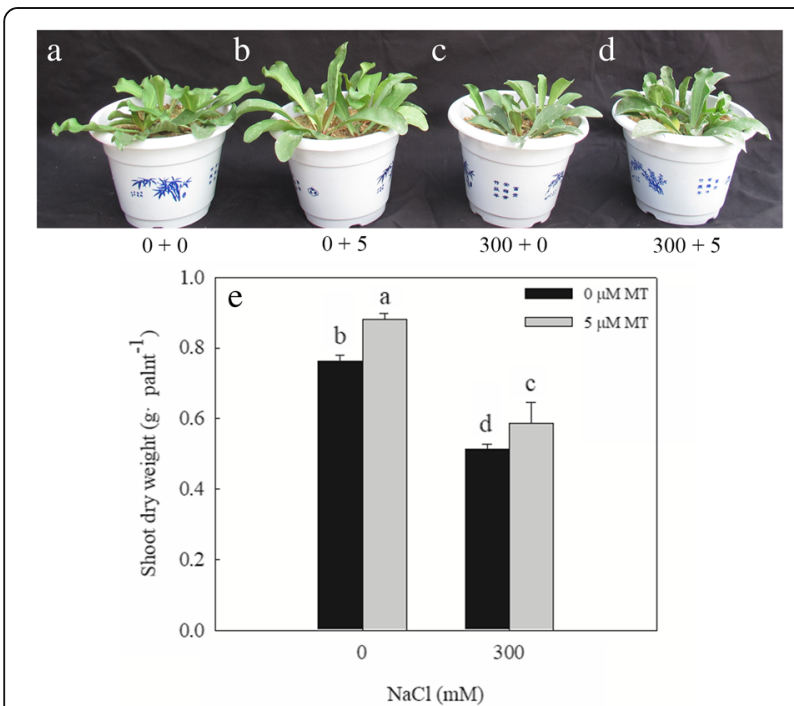

Fig. 1 Effects of exogenous melatonin on the growth of L. bicolor seedlings under salt stress. a-d, the L. bicolor seedlings, after the six-leaf seedlings with $\mathrm{NaCl}$ and melatonin (MT) treatment for 15 consecutive days. $\mathbf{a}, 0+0,0 \mathrm{mM} \mathrm{NaCl}+0 \mu \mathrm{M} \mathrm{MT} ; \mathbf{b}, 0+5,0 \mathrm{mM}$ $\mathrm{NaCl}+5 \mu \mathrm{M} \mathrm{MT} ; \mathbf{c}, 300+0,300 \mathrm{mM} \mathrm{NaCl}+0 \mu \mathrm{M} \mathrm{MT} ; \mathrm{D}, 300+5,300$ $\mathrm{mM} \mathrm{NaCl}+5 \mu \mathrm{M} \mathrm{MT}$; e, the shoot dry weight of $L$. bicolor seedlings. The values are the average of five biological repeats \pm standard deviation. According to Duncan's multi-range tests, bars that there were significant differences at $P<0.05$ are labeled with different letters and the total number of salt glands on a single leaf. The exogenous melatonin treatment had no significant effect on the density of the salt glands on the leaves of plants subjected to either 0 or $300 \mathrm{mM} \mathrm{NaCl}$ (Fig. 2a-e). In contrast, the melatonin treatment significantly increased the total number of salt glands produced by each leaf (25.5 and $41.2 \%$ increases in the 0 - and $300-\mathrm{mM} \mathrm{NaCl}-$ treated plants, respectively; Fig. 2f).

\section{$\mathrm{NaCl}$ and exogenous melatonin increase the endogenous} content of melatonin in L. bicolor leaves

The endogenous melatonin content of the L. bicolor leaves significantly increased under the $300 \mathrm{mM} \mathrm{NaCl}$ treatment (Fig. 3). The exogenous melatonin treatment significantly increased the endogenous melatonin content of the L. bicolor leaves, with increases of $97.5 \%$ in the $0 \mathrm{mM} \mathrm{NaCl}$-treated plants and $19.1 \%$ in the $300 \mathrm{mM}$ $\mathrm{NaCl}$-treated plants.

\section{Melatonin improves ionic homeostasis under $\mathrm{NaCl}$ stress} Salt stress leads to an ionic imbalance in plants by increasing the content of $\mathrm{Na}^{+}$and decreasing the content of $\mathrm{K}^{+}$, resulting in the inhibition of plant growth and development, and possibly even plant death. Treatment with $300 \mathrm{mM} \mathrm{NaCl}$ significantly increased the $\mathrm{Na}^{+}$ (Fig. 4a) and $\mathrm{Cl}^{-}$(Fig. 4b) contents of the L. bicolor leaves, while significantly decreasing the $\mathrm{K}^{+}$(Fig. 4c) content and the $\mathrm{K}^{+} / \mathrm{Na}^{+}$ratio (Fig. $4 \mathrm{~d}$ ). The exogenous melatonin treatment significantly decreased the $\mathrm{Na}^{+}$and $\mathrm{Cl}^{-}$contents of seedlings subjected to the $300 \mathrm{mM} \mathrm{NaCl}$ treatment, while significantly increasing the $\mathrm{K}^{+}$content and the $\mathrm{K}^{+} / \mathrm{Na}^{+}$ratio. These results indicate that melatonin maintains the ion homeostasis of $L$. bicolor leaves under salt stress.

\section{Melatonin promotes salt secretion from the salt glands} L.bicolor is a typical recretohalophyte and its growth and development in high-salt environments are closely related to its salt-secretion ability. The $300 \mathrm{mM} \mathrm{NaCl}$ treatment significantly increased the amount of salt secreted from a single leaf and a single salt gland (Fig. 5c, e, and f). Salt secretions also significantly increased following the $5 \mu \mathrm{M}$ melatonin treatment, both in the 0 and 300-mM NaCl-treated plants. Under $0 \mathrm{mM} \mathrm{NaCl}$, $5 \mu \mathrm{M}$ melatonin had no significant effect on the amount of salt secreted from a single salt gland, although the melatonin treatment significantly increased the amount of salt secreted from a single salt gland in the saltstressed plants.

Melatonin upregulates the expression of ion transporter and vesicle transport genes

We examined the effect of melatonin treatment on the expression levels of ion transporter-related genes in salt- 

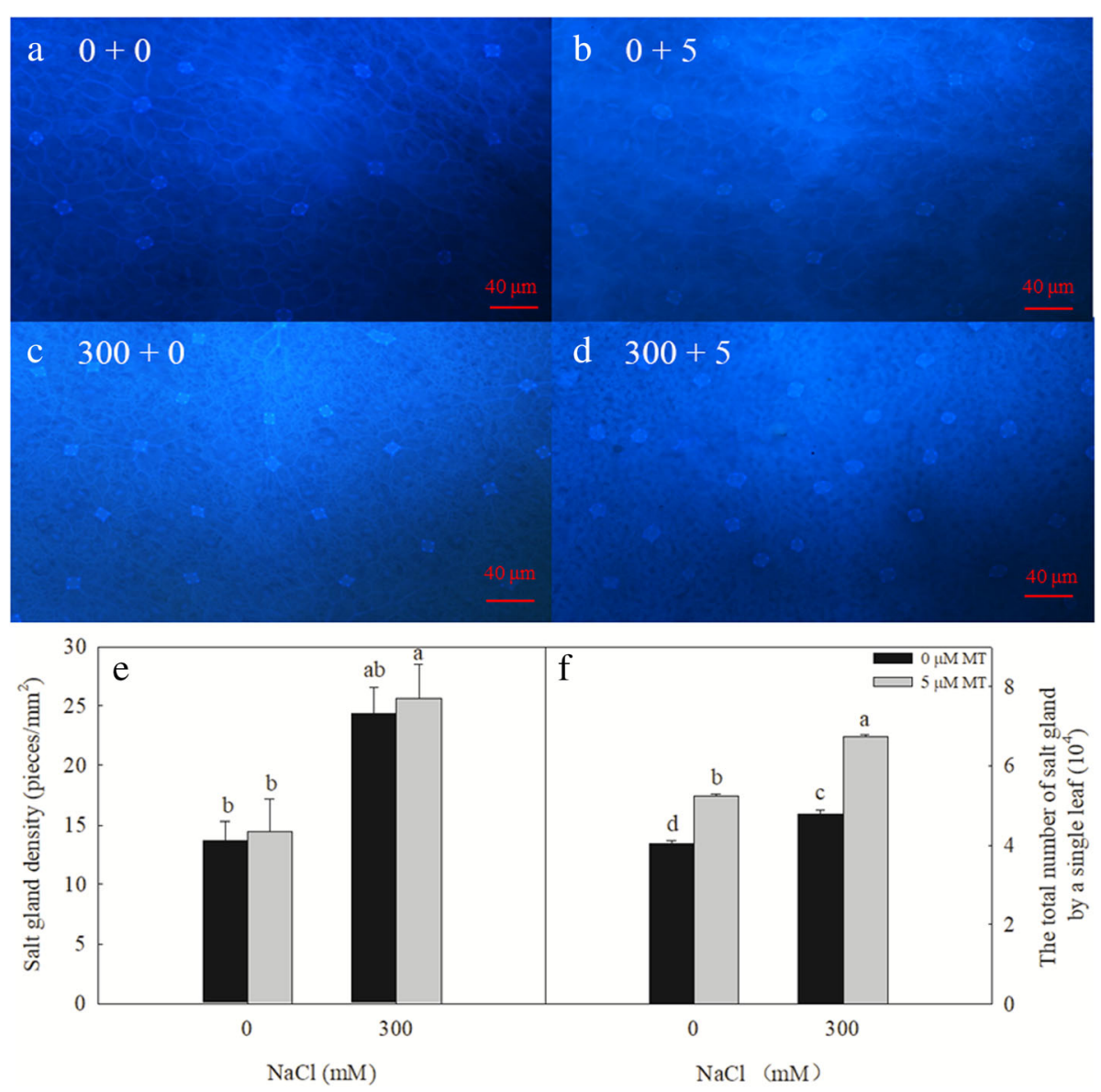

Fig. 2 Effects of $\mathrm{NaCl}$ and melatonin on the density of salt gland and total number of salt glands of a single leaf. a-d, the density of salt glands of L. bicolor leaves, $\mathbf{a}, 0+0,0 \mathrm{mM} \mathrm{NaCl}+0 \mu \mathrm{M} \mathrm{MT} ; \mathbf{b}, 0+5,0 \mathrm{mM} \mathrm{NaCl}+5 \mu \mathrm{M} \mathrm{MT} ; \mathbf{c}, 300+0,300 \mathrm{mM} \mathrm{NaCl}+0 \mu \mathrm{M} \mathrm{MT} ; \mathbf{d}, 300+5,300 \mathrm{mM} \mathrm{NaCl}+$ $5 \mu \mathrm{M} \mathrm{MT} ; \mathbf{e}$, the density of salt glands of L. bicolor leaves; $\mathbf{f}$, total number of salt glands of a single leaf. Bar $=40 \mu \mathrm{m}$. Arrows indicate salt glands. The values are the average of five biological repeats \pm standard deviation. According to Duncan's multi-range tests, bars that there were significant differences at $P<0.05$ are labeled with different letters

stressed plants. Following the $300 \mathrm{mM} \mathrm{NaCl}$ treatment, the expression levels of LbSOS1 were significantly upregulated after 24, 36, 48, and $72 \mathrm{~h}$ (Fig. 6a); LbPMA was upregulated after 24h (Fig. 6b); LbHKT1 (high-affinity potassium transporter 1) was upregulated after 12, 24, 36, 48, and $72 \mathrm{~h}$ (Fig. 6c); and LbNHX1 was upregulated after $24 \mathrm{~h}$ and $36 \mathrm{~h}$ (Fig. $6 \mathrm{~d}$ ), relative to the control. The $5 \mu \mathrm{M}$ melatonin treatment significantly upregulated the expression levels of LbSOS1 after 24, 36, 48, and $72 \mathrm{~h}$ (Fig. 6a); LbPMA after 24 h (Fig. 6b); LbHKT1 after 12, 24, 36, 48, and $72 \mathrm{~h}$ (Fig. 6c); and LbNHX1 after $24 \mathrm{~h}$ and $36 \mathrm{~h}$ (Fig. 6d), relative to the control. The combination of the $300 \mathrm{mM} \mathrm{NaCl}$ and $5 \mu \mathrm{M}$ melatonin treatments significantly upregulated the expression levels of LbSOS1, LbPMA, LbHKT1, and LbNHX1 after 12, 24, 36, 48, and $72 \mathrm{~h}$ (Fig. 6).

We also measured the expression levels of the vesicle transport-related genes in plants subjected to various salt and melatonin treatments. The $300 \mathrm{mM} \mathrm{NaCl}$ treatment significantly upregulated the expression levels of $L b V A M P 721$ after 24, 36, 48, and $72 \mathrm{~h}$; LbVAP27 after $24 \mathrm{~h}$; and $L b V A M P 121$ after 24 and $48 \mathrm{~h}$. The $5 \mu \mathrm{M}$ melatonin treatment significantly upregulated the expression levels of $L b V A M P 721$ after 24, 36, and $48 \mathrm{~h}$; LbVAP27 after $24 \mathrm{~h}$; and LbVAMP121 after 24 and $36 \mathrm{~h}$. The combination of the $300 \mathrm{mM} \mathrm{NaCl}$ and $5 \mu \mathrm{M}$ melatonin treatments significantly upregulated the expression levels of LbVAMP721 after 12, 24, 36, 48, and $72 \mathrm{~h}$ (Fig. 7a); LbVAP27 after 12, 24, 36, and $48 \mathrm{~h}$ (Fig. 7b); and LbVAMP121 after 24, 36, and $48 \mathrm{~h}$ (Fig. 7c).

\section{Discussion}

Salinity is a wide-ranging environmental stress factor that severely inhibits plant growth and development, reduces crop yield, and even causes plant death [1, 43, 44]. Many plants have developed mechanisms to secrete or tolerate the salts in their cells. The recretohalophyte $L$. bicolor has a strong but poorly understood salt secretion 


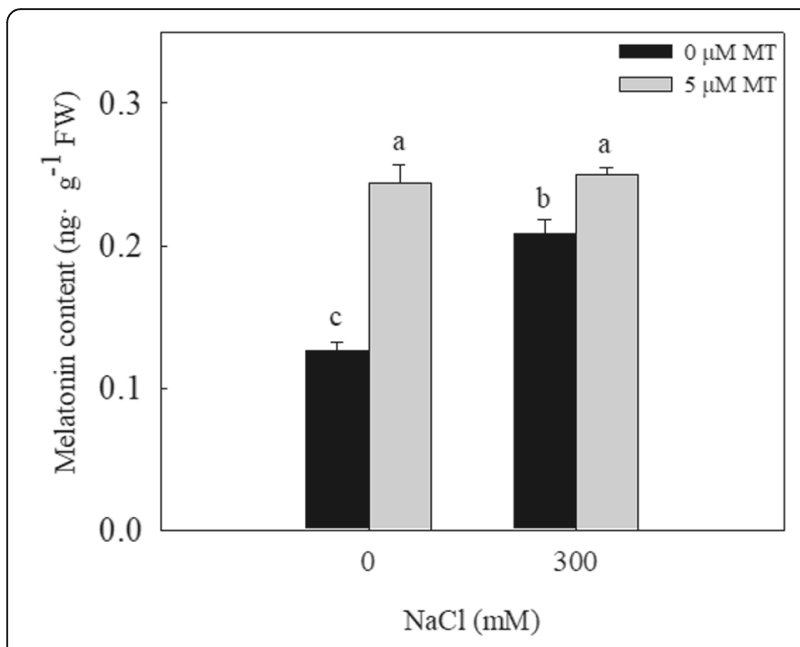

Fig. 3 The melatonin content of L. bicolor leaves under melatonin and $\mathrm{NaCl}$ treatment. The values are the average of five biological repeats \pm standard deviation. According to Duncan's multi-range tests, bars that there were significant differences at $P<0.05$ are labeled with different letters

ability, and can therefore be used as a model species to study the development and function of |salt glands [3]. In this study, we revealed that exogenous melatonin significantly increased the ability of the L. bicolor salt glands to secrete salt by upregulating the expression of genes encoding ion transporters and vesicle transport proteins, which can increase the salt tolerance of this plant and enable it to grow well in heavily saline soils. This discovery provides a basis for us to further elucidate the salt secretion mechanism of the salt glands in future studies.

Salinity impairs plant growth first by causing osmotic stress, and then ion stress as the salt ions enter the plant body [45-47]. Yuan et al. [3, 23] reported that the growth of L. bicolor is inhibited under high-salt conditions $(200 \mathrm{mM}$ or more). In the present study, we established that exogenous melatonin application alleviated the inhibition of L. bicolor growth caused by treatment with $300 \mathrm{mM} \mathrm{NaCl}$ (Fig. 1). This is the first report of this phenomenon in a halophyte. Since even halophytes cannot tolerate large amounts of $\mathrm{Na}^{+}$ and $\mathrm{Cl}^{-}$in their cytoplasm, they either compartmentalize excess ions into vacuoles or transport ions into different tissues to maintain cytoplasmic ion homeostasis $[1,48,49]$.

As a typical recretohalophyte, $L$. bicolor can excrete excess salts via its salt glands $[3,9]$, which reduces its $\mathrm{Na}^{+}$ and $\mathrm{Cl}^{-}$contents while increasing the $\mathrm{K}^{+} / \mathrm{Na}^{+}$ratio observed in the leaves (Fig. 4), promoting salt tolerance. The salt secretion rate of the leaves depends on the density and function of the salt glands [10]. Here, we showed that the density of the L. bicolor salt glands increased significantly under the independent salt stress, independent melatonin, and combined salt and melatonin treatment (Fig. 2). The increased number and function of salt glands correspondingly enhanced the salt secretion ability of the leaves, which decreased their salt contents and promoted the growth of L. bicolor (Figs. 1 and 5).

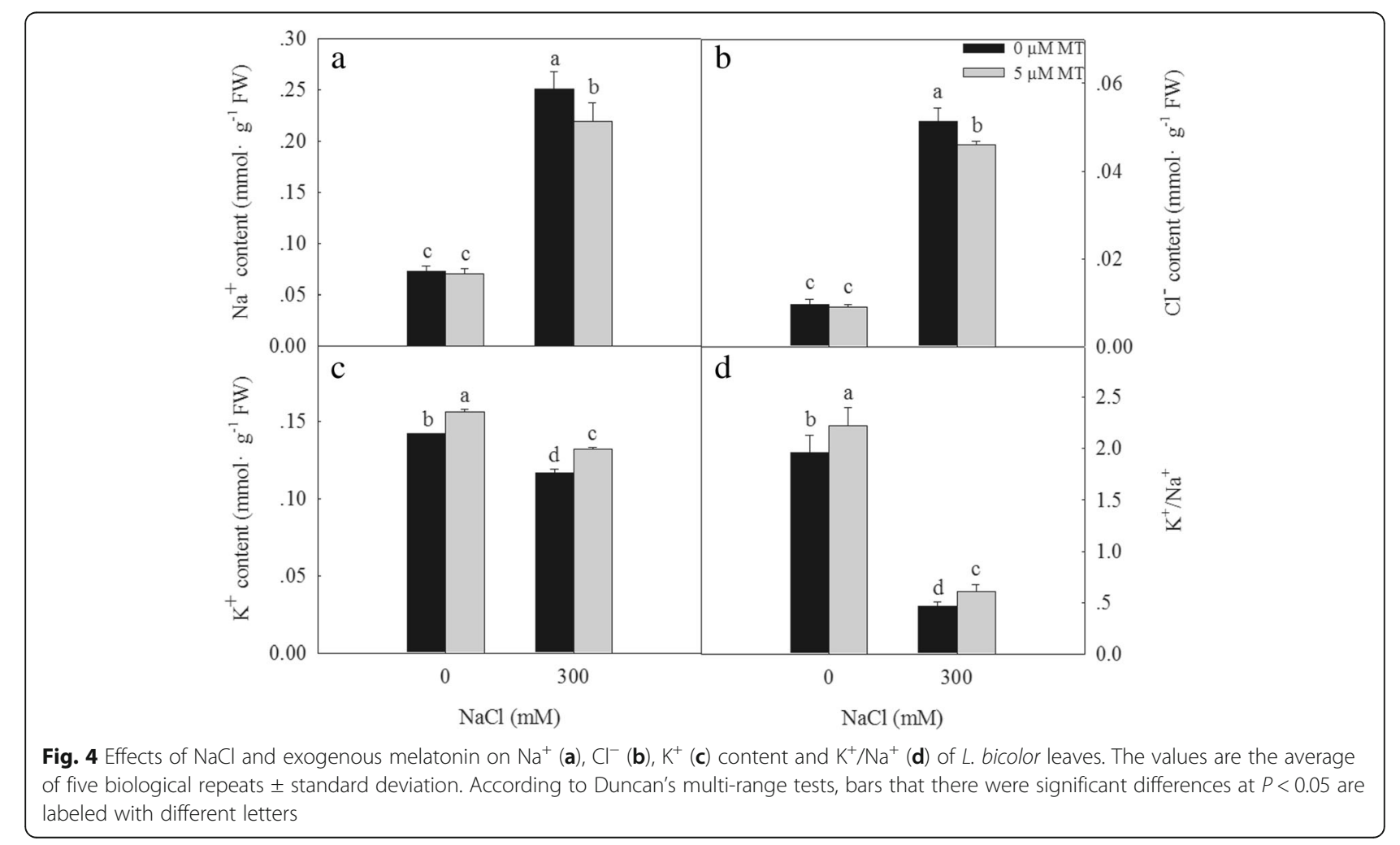



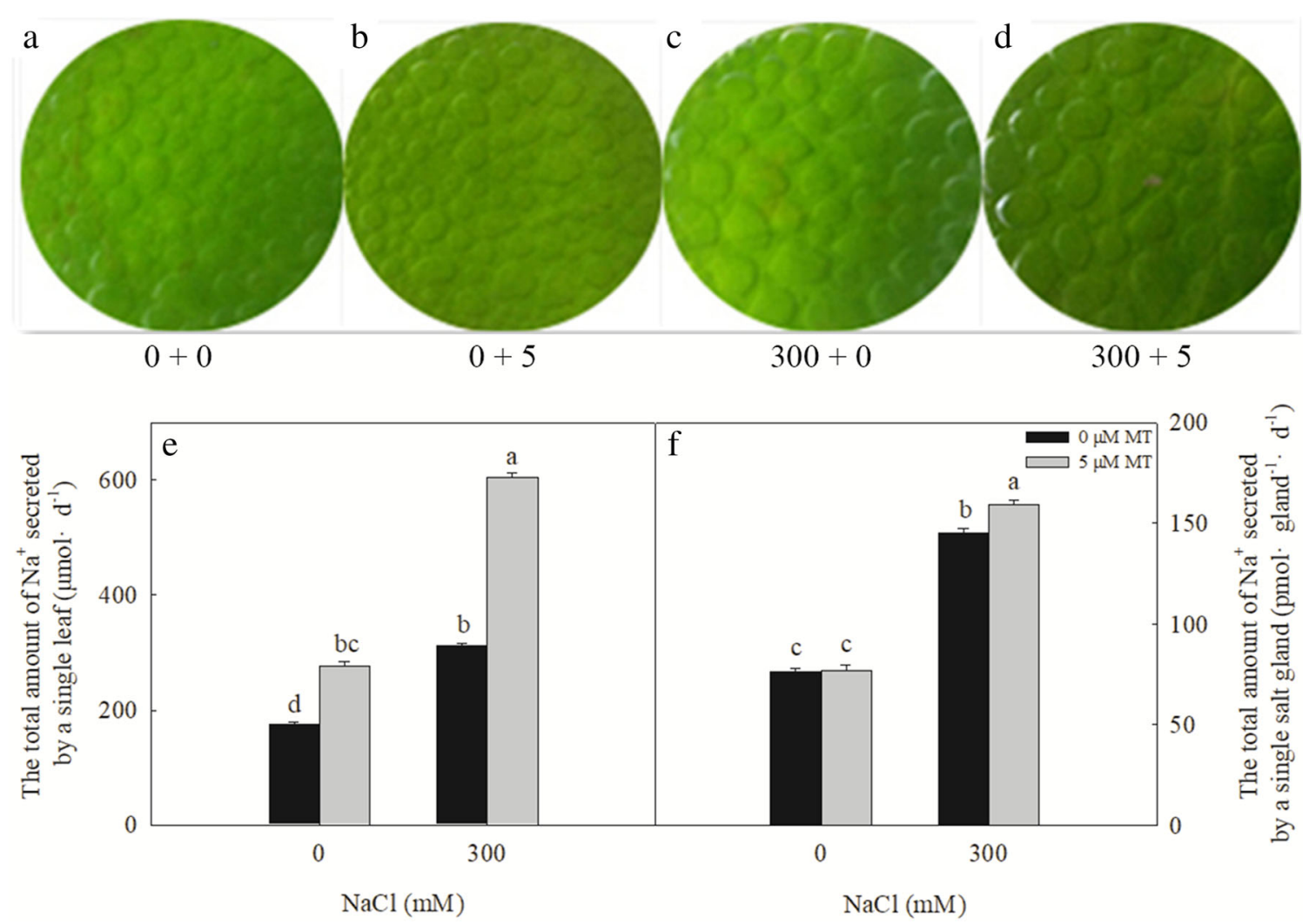

Fig. 5 Effects of $\mathrm{NaCl}$ and melatonin on salt secretion of salt glands of $L$. bicolor leaves. a-d, the ability of salt secretion of leaves with leaf disc method, a, 0 + 0, $0 \mathrm{mM} \mathrm{NaCl}+0 \mu \mathrm{M} \mathrm{MT} ; \mathbf{b}, 0+5,0 \mathrm{mM} \mathrm{NaCl}+5 \mu \mathrm{M} \mathrm{MT} ; \mathbf{c}, 300+0,300 \mathrm{mM} \mathrm{NaCl}+0 \mu \mathrm{M} \mathrm{MT} ; \mathbf{d}, 300$ + 5, $300 \mathrm{mM} \mathrm{NaCl}+5 \mu \mathrm{M} \mathrm{MT} ; \mathbf{e}$, The total amount of $\mathrm{Na}^{+}$secreted by a single leaf; $\mathbf{f}$, the total amount of $\mathrm{Na}^{+}$secreted by a salt gland. The values are the average of five biological repeats \pm standard deviation. According to Duncan's multi-range tests, bars that there were significant differences at $P<0.05$ are labeled with different letters

The secretion rate of the salt glands is affected by many factors [8]. In the present study, exogenous melatonin significantly increased the salt secretion rate of the salt glands and the amount of salt secreted by a single leaf of $L$. bicolor compared with leaves under salt stress alone (Fig. 5). Previous studies have indicated that ion transporters and vesicular transport proteins are involved in salt secretion from the salt glands [12, 17]. In $L$. bicolor leaves, the expression levels of the ion transport-related genes, LbSOS1, LbPMA, LbHKT1, and $L b N H X 1$, were upregulated after the application of exogenous melatonin (Fig. 6). SOS1, HKT1, and NHX1 are important ion transport proteins in plants [50]. PMA can provide the driving force for SOS1, and their expression level is positively related to the salt tolerance of plants [50]. Liu et al. [31] showed that exogenous melatonin can upregulate the expression of genes encoding important $\mathrm{Na}^{+}$-detoxification transporters under salt stress [31]. Recently, studies have indicated that the exogenous application of melatonin can improve the ion homeostasis of plants under salt stress by upregulating the expression of genes encoding NHX, SOS and other proteins with related functions [30, 51, 52]. Yuan et al. [9] proposed that LbSOS1, LbPMA, and LbHKT1 participate in the salt secretion process, which is consistent with the finding that exogenous melatonin increases the salt secretion rate of the salt glands by upregulating the expression of the ion transport genes. These results indicate that ion transport proteins participate in the salt secretion process in L. bicolor.

Ziegler and Lüttge [12] reported that vesicle transport proteins mediate the salt secretion process in the salt glands in the related species L. vulgare. Yuan et al. [9] proposed that small vesicles may be involved in transporting salt into and out of the salt glands, which is supported by the results of Lu et al. [26] for L. bicolor. We established that the expression levels of the vesicle transport-related genes LbVAMP721, LbVAP27, and LbVAMP121 were also upregulated by the melatonin treatment (Fig. 7), which suggested that the vesicle transport proteins can participate in the salt secretion process in this species; however, further research is needed to decipher the mechanism by which exogenous melatonin regulates $\mathrm{Na}^{+}$secretion from the salt gland. 


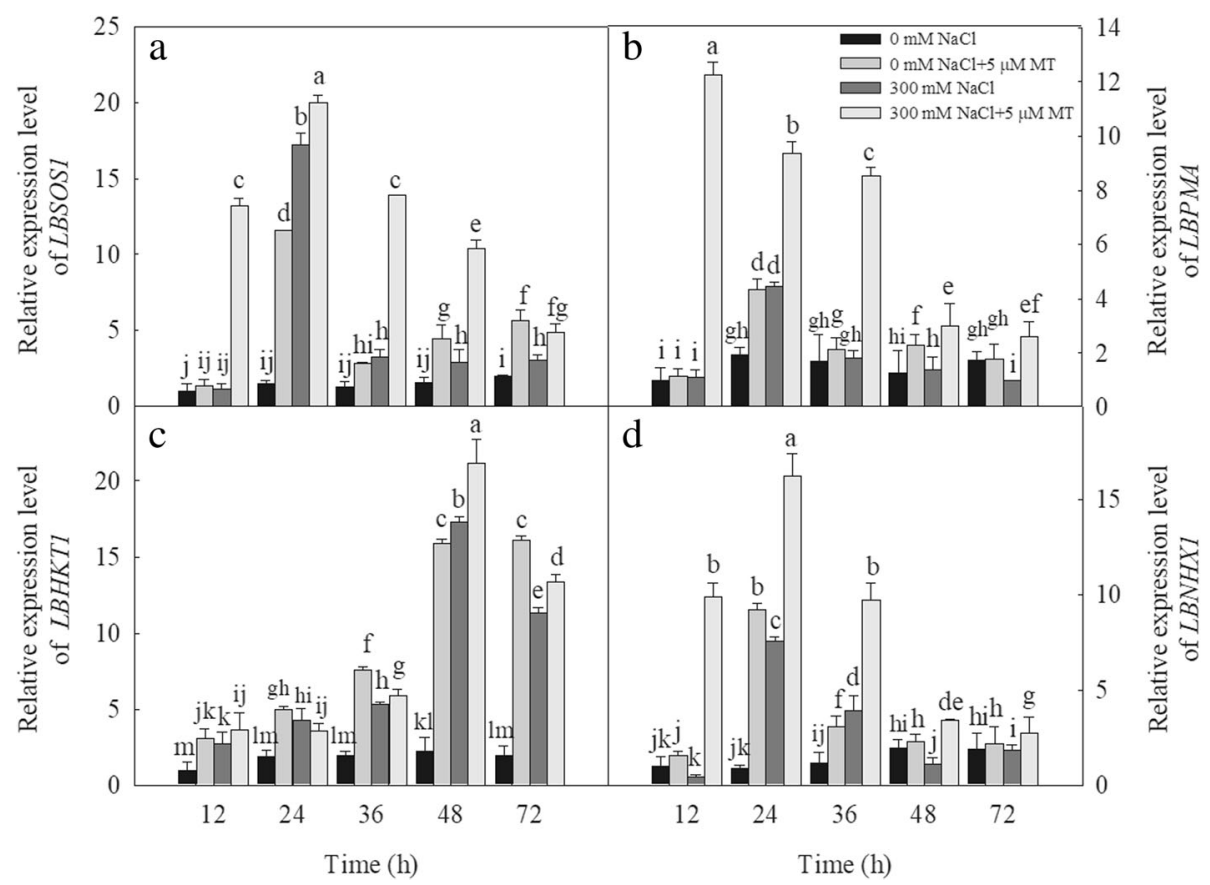

Fig. 6 Effects of $\mathrm{NaCl}$ and melatonin on ions transporter genes (LBSOS1, LBPMA, LBHKT1 and LBNHX1) expression in L. bicolor leaves in 6-wk-old seedlings at different time points after $\mathrm{NaCl}(300 \mathrm{mM})$ and melatonin $(5 \mu \mathrm{M})$ treatment. (a) Transcript level of LBSOS1 (salt overly sensitive 1), (b) Transcript level of LBPMA ( $H^{+}$-ATPase genes), (c) Transcript level of $L B H K T 1$ (high-affinity $K^{+}$transporter 1), (d) Transcript level of $L B N H X 1$ (tonoplast $\mathrm{Na}^{+} / \mathrm{H}^{+}$antiporter). The values are the average of three biological repeats \pm standard deviation. According to Duncan's multi-range tests, bars that there were significant differences at $P<0.05$ are labeled with different letters

Our results showed that melatonin can upregulate the expression of genes encoding ion transporters and vesicle transport proteins to enhance salt secretion from the salt glands. Combining the results of the current study with previous research, we formulated a novel mechanism by which melatonin increases salt secretion in L. bicolor (Fig. 8). Melatonin upregulates the expression of genes encoding ion transporters and vesicle transport proteins. The ion transporters transport ions into the salt glands. Ions in the salt glands are transported to the collecting chamber adjacent to the secretory pore through vesicle transport and ions transporter and then are secreted from the secretory pore of salt glands, which maintain ionic homeostasis in the cells and alleviate $\mathrm{NaCl}$-induced growth inhibition.

\section{Methods}

\section{Plant materials and growth conditions}

L. bicolor seeds were kindly provided by Professor $\mathrm{Xu}$ Hualing, Dongying Academy of Agricultural Sciences, Shandong Province. The seeds were sterilized in $0.5 \%$ (w/v) sodium hypochlorite solution for $15 \mathrm{~min}$ and then cleaned with sterile-distilled water. The seeds were sown on well-washed river sand in plastic pots $(16 \mathrm{~cm}$ in diameter; after the leaves emerged, the plants were watered with Hoagland's nutrient solution), which were placed in a growth chamber with $600 \mu \mathrm{mol} \mathrm{m}^{-2} \mathrm{~s}^{-1}$ light (15-h day/9-h night photoperiod), a temperature of $25 \pm$ $3{ }^{\circ} \mathrm{C} / 22 \pm 3{ }^{\circ} \mathrm{C}$ (day/night), and a relative humidity of $60 /$ $80 \%$ (day/night).

\section{Combined $\mathrm{NaCl}$ and melatonin treatment}

When the seedlings reached the six-leaf stage, they were subjected to $\mathrm{NaCl}$ and melatonin treatments. For the $\mathrm{NaCl}$ treatment, the seedlings were treated with Hoagland's nutrient solution containing $\mathrm{NaCl}$, which was increased by $50 \mathrm{mM}$ every $12 \mathrm{~h}$ to a final concentration of $300 \mathrm{mM}$ to avoid salt shock. When the $\mathrm{NaCl}$ concentration reached $300 \mathrm{mM}$, melatonin treatment starts, which will treat for 15 days. The control seedlings were treated with Hoagland's nutrient solution only. To research the effects of melatonin on salt tolerance in L. bicolor, the $\mathrm{NaCl}$-treated (the $\mathrm{NaCl}$ concentration gradually increased to $300 \mathrm{mM}$ ) and control seedlings were irrigated with 0 or $5 \mu \mathrm{M}$ melatonin (based on the pre-test with various concentrations of melatonin, Fig. S1), which dissolves in the above Hoagland's nutrient solution. The $L$. bicolor seedlings were treated with various combinations of salt and melatonin every $12 \mathrm{~h}$ for 15 consecutive days. Five replicates (3 plants per replicate) were performed for each treatment. After 15 days, the leaves were collected to determine the biological indicators. 


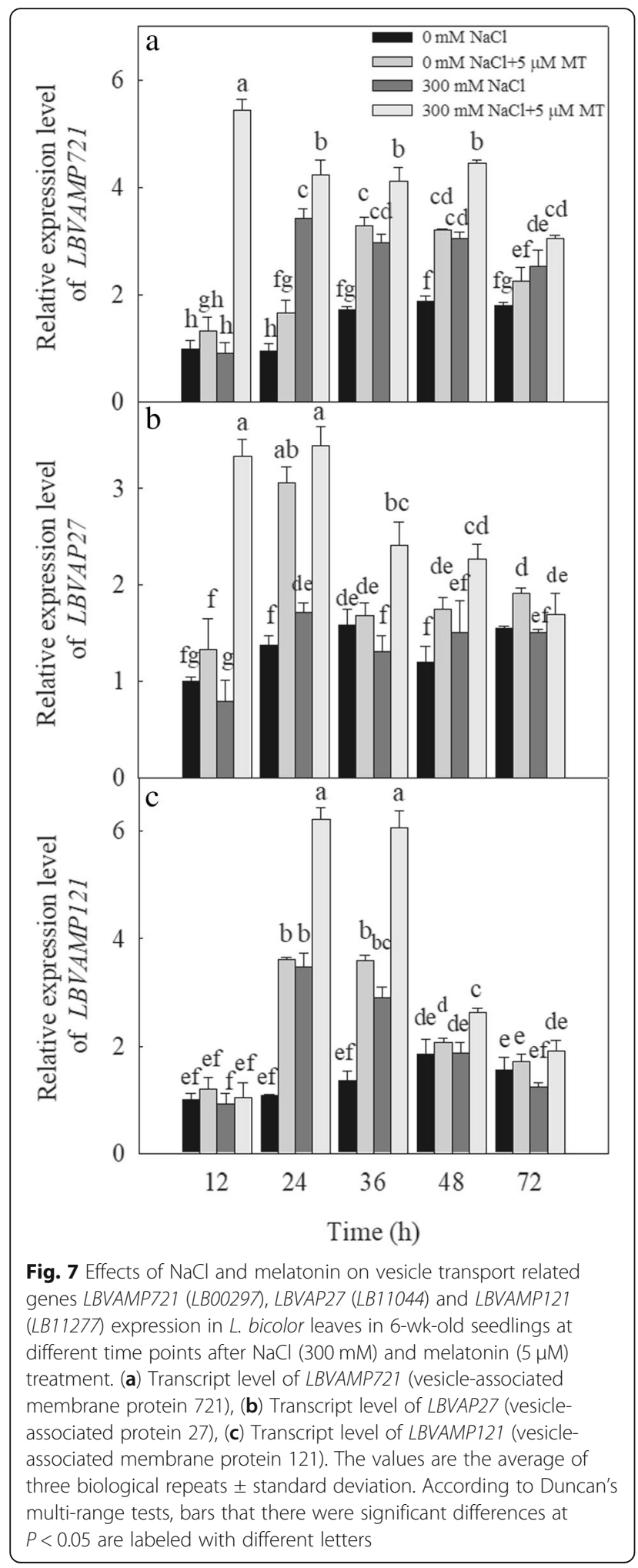

\section{Physiological index measurements}

The dry weights of seedlings after 15 days of the treatments were measured as described by Yuan et al. [10]

\section{Melatonin quantification}

The melatonin content of $L$. bicolor leaves was quantified as described by Sun et al. [53]. Briefly, $0.3 \mathrm{~g} \mathrm{~L}$. bicolor leaves were ground into powder in liquid nitrogen, mixed well with $1.5 \mathrm{~mL}$ methanol, and incubated overnight at $4{ }^{\circ} \mathrm{C}$. The solutions were centrifuged for $10 \mathrm{~min}$ at $10,000 \times g$ at $4{ }^{\circ} \mathrm{C}$, after which the supernatant was transferred into new test tubes and the liquid was allowed to evaporate. The remaining residues were dissolved in $0.75 \mathrm{~mL}$ methanol. A fluorescence detector system (L3000; Rigol Technologies, Beijing, China) was used to determine the melatonin concentration by the area of the peaks identified during high-performance liquid chromatography.

\section{Ion content measurement}

Leaf samples ( $5 \mathrm{~g}$ ) were placed into test tubes containing $10 \mathrm{~mL} \mathrm{ddH}_{2} \mathrm{O}$ and the tubes were placed in a boiling water bath for $3 \mathrm{~h}$, after which the samples were filtered through filter paper. The supernatant was made up to a volume of $25 \mathrm{~mL}$ with $\mathrm{ddH}_{2} \mathrm{O}$. The $\mathrm{Na}^{+}$and $\mathrm{K}^{+}$contents were measured using a flame spectrophotometer (Model 2655-00 Digital Flame Analyzer; Cole-Parmer Instrument Company, Vernon Hills, Illinois, USA), and the $\mathrm{Cl}^{-}$content was measured using an ion chromatograph (ICS-1100 ion chromatograph; Thermo Fisher Scientific, Waltham, MA, USA), as described by Lin et al. [54]

\section{Characterization of the $L$. bicolor salt glands}

L. bicolor leaves (Fig. S2) were cleared using Carnoy's solution (mixed solution of ethanol and acetic acid (3:1, v/ v)), as described by Kuwabara and Nagata [55](2016), after which they were fixed onto microscope slides using Hoyer's solution [56](Yuan et al., 2014). The diameters and densities of the salt glands were determined using a Nikon fluorescence microscope (ECLIPSE 80i; Nikon, Tokyo, Japan) at $\times 200$ and $\times 100$ magnifications with a standard DAPI filter set under UV excitation (330-380 $\mathrm{nm})$. Digital images were taken using a charge-coupled device camera. Fifteen leaves were measured per treatment, with the measurements taken at the same position on each leaf. The salt glands were counted for a given leaf area to calculate the salt gland density on the abaxial surfaces of the leaves [17]. The total number of salt glands is equal to the salt gland density multiplied by the leaf area. The salt secretion levels under different $\mathrm{NaCl}$ and melatonin treatments were determined using the leaf disk method, as described by Lu et al. [26].

\section{qRT-PCR analysis}

The nucleotide sequences of ion homeostasis (LbHTK1, LbSOS1, LbPMA, and LbNHX1) and vesicle transport (LbVAMP721 (vesicle-associated membrane protein 721), LbVAP27 (syntaxin from plants 27), and LbVAMP121 


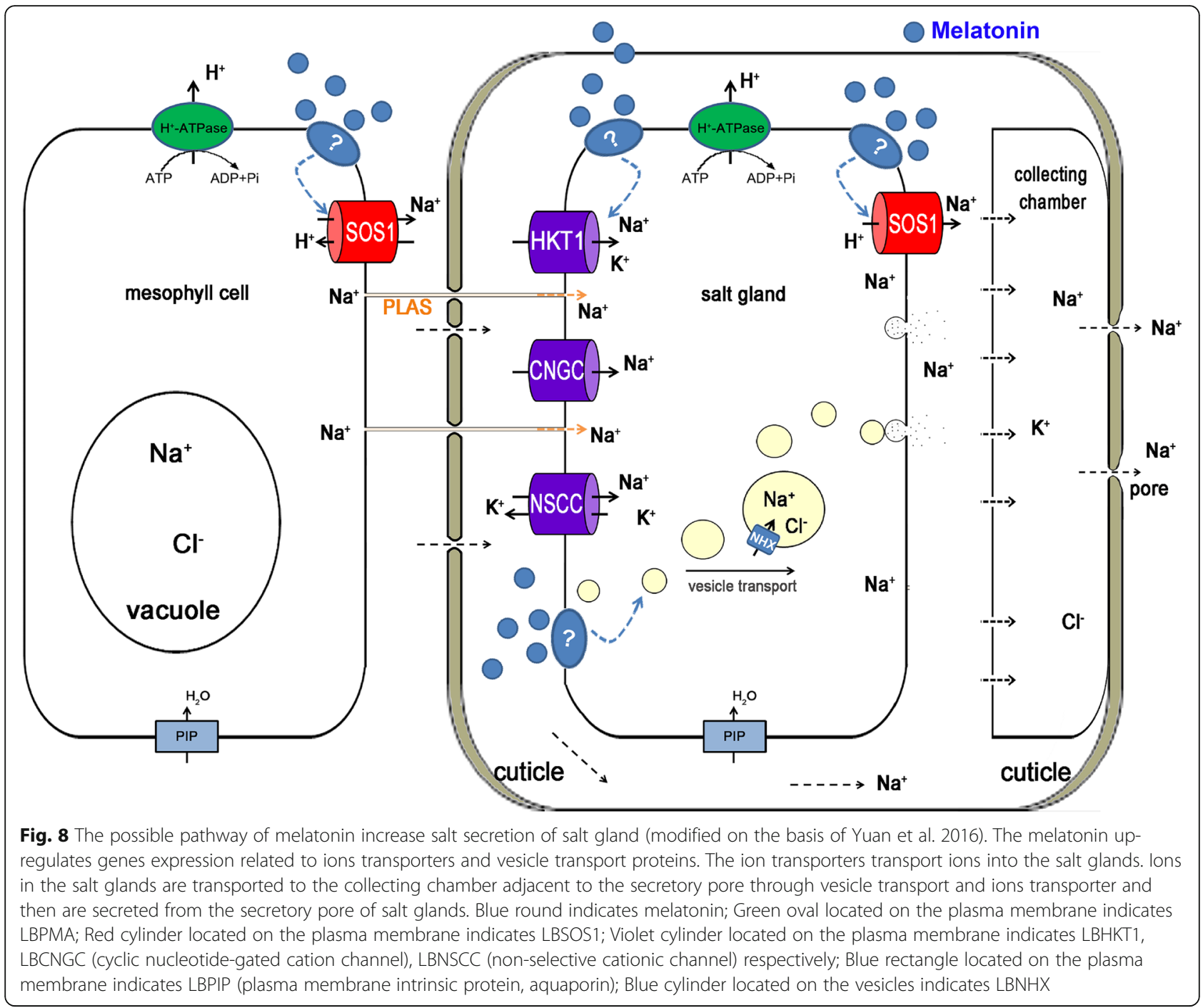

(vesicle-associated membrane protein 721)) genes in L. bicolor were obtained according to the second-and third-generation RNA sequences [3]. A BLAST search for homologous genes was carried out in both $L$. bicolor and other species, and homologous sequences were downloaded. Primers were designed for cloning the conserved region sequences $(800 \mathrm{bp})$. The conserved region sequences of $L b H T K 1, L b S O S 1, L b P M A$, LbNHX1, LbVAMP721, LbVAP27, and LbVAMP121 were obtained. Beacon Designer (Premier Biosoft, Palo Alto, California, USA) was used to design primers for these seven genes (Table S1). AceQ Universal SYBR Green qPCR Master Mix (Vazyme Biotech, Nanjing, China) and a real-time quantitative PCR instrument (Bio-Rad Laboratories, Hercules, California, USA) were used to perform the real-time PCR. The relative expression of each gene was calculated using the $2^{-\triangle \Delta C t}$ method [17, 57], with the housekeeping gene LbTUBULIN used as an internal reference.

\section{Statistical analysis}

The statistical analysis was performed using the SPSS software package (version 19.0; IBM, Armonk, New York, USA). The statistical significance was determined using an analysis of variance (ANOVA), and significant differences $(P<0.05)$ between the values were determined using Duncan's multiple range test.

\section{Supplementary information}

Supplementary information accompanies this paper at https://doi.org/10. 1186/s12870-020-02703-x.

Additional file 1: Figure S1. Pre-test with various concentrations of melatonin and found that for the species, $5 \mu \mathrm{M}$ melatonin significantly improved the growth under control and $\mathrm{NaCl}$ treatment.

Additional file 2: Figure S2. Leaves for analyzing characterization of the L. bicolor salt glands.

Additional file 3: Table S1. Primers of candidate genes used for realtime $\mathrm{QPCR}$ analysis.

Additional file 4. All data generated during this study. 


\section{Abbreviations}

MT: melatonin; PM: plasma membrane; PMA: plasma membrane $\mathrm{H}^{+}$-ATPase; SOS1: salt overly sensitive; $\mathrm{NHX1}$ : tonoplast $\mathrm{Na}^{+} / \mathrm{H}^{+}$antiporter 1 ; HKT1: highaffinity potassium transporter 1; VAMP721: vesicle-associated membrane protein 721; VAP27: syntaxin from plants 27; VAMP121: vesicle-associated membrane protein 721

\section{Acknowledgements}

Not applicable.

\section{Authors' contributions}

$M C$ and BW designed the research, JL, FY and $Y L$ performed the experiments, $J$ wrote the paper with contributions from the other authors. $M Z, Y L, Y Z$ analyzed the data. BW revised the paper. All authors read and approved the final manuscript

\section{Funding}

This work was supported by Shandong Provincial "Bohai Granary" Science and Technology Demonstration Project (2019BHLC004), Agricultural Variety Improvement Project of Shandong Province (2019LZGC009) and the major projects of science and technology in Shandong province (2017CXGC0311) and the Program for Scientific Research Innovation Team in Colleges and Universities of Shandong Province.

\section{Availability of data and materials}

Not applicable.

\section{Ethics approval and consent to participate}

Not applicable.

\section{Consent for publication}

Not applicable.

\section{Competing interests}

The authors declare that they have no conflict of interest.

Received: 21 July 2020 Accepted: 14 October 2020 Published online: 27 October 2020

\section{References}

1. Zhu JK. Regulation of ion homeostasis under salt stress. CurrOpin Plant Biol. 2003;6:441-5.

2. Song J, Wang BS. Using euhalophytes to understand salt tolerance and to develop saline agriculture: Suaeda salsa as a promising model. Ann Bot. 2015:115(3):541-53.

3. Yuan F, Lyu MJA, Leng BY, Zhu XG, Wang BS. The transcriptome of $\mathrm{NaCl}$ treated Limonium bicolor, leaves reveals the genes controlling salt secretion of salt gland. Plant Mol Biol. 2016;91:241-56.

4. Evelin H, Kapoor R, Giri B. Arbuscular mycorrhizal fungi inalleviation of salt stress: a review. Ann Bot. 2009;104:1263-80.

5. Song J, Shi GW, Gao B, Fan H, Wang BS. Waterlogging and salinity effects on two Suaeda salsa populations. Physiol Plant. 2011:141:343-51.

6. Sui N, Tian S, Wang W, Wang M, Fan H. Overexpression of glycerol-3phosphate acyltransferase from Suaeda salsa improves salt tolerance in Arabidopsis. Front Plant Sci. 2017;8:1337

7. Li J, Liu J, Zhu T, Zhao C, Li L, Chen M. The role of melatonin in salt stress responses. Int J Mol Sci. 2019;20(7):1735.

8. Levitt J. Responses of plants to environmental stresses. New York: Academic Press; 1972.

9. Yuan F, Leng BY, Wang BS. Progress in studying salt secretion from the salt glands in recretohalophytes: how do plants secrete salt? Front Plant Sci. 2016;7:977-88.

10. Yuan F, Liang X, Li Y, Yin S, Wang B. Methyl jasmonate improves tolerance to high salt stress in the recretohalophyte Limonium bicolor. Funct Plant Biol. 2019:46:82-92.

11. Arisz W, Camphuis I, Heikens H, van Tooren AJ. The secretion of the salt glands of Limonium latifolium Ktze. Acta Botanica Neerlandica. 1955:4:322 38

12. Ziegler H, Lüttge U. Die Salzdrüsen von Limonium vulgare. Planta. 1967; 74(1):1-17.
13. Shimony C, Fahn A. Light-and electron-microscopical studies on the structure of salt glands of Tamarix aphylla L. Bot J Linn Soc. 1968;60(383): 283-8.

14. Feng Z, Sun Q, Deng Y, Sun S, Zhang J, Wang B. Study on pathway and characteristics of ion secretion of salt glands of Limonium bicolor. Acta Physiol Plant. 2014:36:2729-41.

15. Levering CA, Thomson WW. The ultrastructure of the salt gland of Spartina foliosa. Planta. 1971:97:183-96.

16. Shi H, Quintero FJ, Pardo JM, Zhu JK. The putative plasma membrane $\mathrm{Na}^{+}$/ $\mathrm{H}^{+}$antiporter SOS1 controls long-distance $\mathrm{Na}^{+}$transport in plants. Plant Cell. 2002:14:465-77.

17. Ding F, Chen M, Sui N, Wang BS. $\mathrm{Ca}^{2+}$ significantly enhanced development and salt-secretion rate of salt glands of Limonium bicolor under $\mathrm{NaCl}$ treatment. S Afr J Bot. 2010;76:95-101.

18. Gao $C$, Wang $Y$, Jiang $B$, et al. A novel vacuolar membrane $H^{+}$-ATPase $c$ subunit gene (ThVHAc1) from Tamarix hispida confers tolerance to several abiotic stresses in Saccharomyces cerevisiae. Mol Biol Rep. 2011:38(2):95763.

19. Tan WK, Lim TM, Loh CS. A simple, rapid method to isolate salt glands for three-dimensional visualization, fluorescence imaging and cytological studies. Plant Methods. 2010:6:24-35.

20. Dang ZH, Zheng LL, Wang J, Gao Z, Wu SB, Qi Z, et al. Transcriptomic profiling of the salt-stress response in the wild recretohalophyte Reaumuria trigyna. BMC Genomics. 2013;14:29. https://doi.org/10.1186/1471-2164-14-29.

21. Barkla BJ, Zingarelli L, Blumwald E, Smith JAC. Tonoplast $\mathrm{Na}^{+} / \mathrm{H}^{+}$antiporter activity and its energization by the vacuolar $\mathrm{H}^{+}$-ATPase in the halophytic plant Mesembryanthemum crystallinum L. Plant Physiol. 1995;109:549-56.

22. Feng ZT, Deng YQ, Zhang SC, Liang X, Yuan F, Hao JL, Zhang JC, Sun SF, Wang BS. $\mathrm{K}^{+}$accumulation in the cytoplasm and nucleus of the salt gland cells of Limonium bicolor accompanies increased rates of salt secretion under $\mathrm{NaCl}$ treatment using NanoSIMS. Plant Sci. 2015;238:286-96.

23. Yuan F, Lyu MJ, Leng BY, Zheng GY, Feng ZT, Li PH, Zhu XG, Wang BS. Comparative transcriptome analysis of developmental stages of the Limonium bicolor leaf generates insights into salt gland differentiation. Plant Cell Environ. 2015;38:1637-57

24. Thomson WW, Liu LL. Ultrastructural features of the salt gland of Tamarix aphylla L. Planta. 1967;73:201-20.

25. Flowers TJ, Glenn EP, Volkov V. Could vesicular transport of $\mathrm{Na}^{+}$and $\mathrm{Cl}^{-}$be a feature of salt tolerance in halophytes? Ann Bot. 2019;123(1):1-18.

26. Lu C, Feng Z, Yuan F, Han G, Guo J, Chen M, Wang B. The SNARE protein LbSYP61 participates in salt secretion in Limonium bicolor. Environmental and Experimental Botany Available online 24 April 2020, 104076, https://doi. org/10.1016/j.envexpbot.2020.104076

27. Rozema J, Riphagen I. Physiology and ecologic relevance of salt secretion by the salt gland of Glaux maritima L. Oecologia. 1977;29(4): 349-57.

28. Hattori A, Migitaka H, ligo M, Itoh M, Yamamoto K, Ohtani-Kaneko R, Hara M, Suzuki T, Reiter RJ. Identification of melatonin in plants and its effects on plasma melatonin levels and binding to melatonin receptors in vertebrates. Biochem Mol Boil Int. 1995;35:627-34

29. Dubbels R, Reiter RJ, Klenke E, Goebel A, Schnakenberg E, Ehlers C, Schiwara $\mathrm{HW}$, Schloot W. Melatonin in edible plants identified by radioimmunoassay and by high performance liquid chromatography-mass spectrometry. J Pineal Re. 1995;18:28-31.

30. Li C, Wang P, Wei Z, Liang D, Liu C, Yin L, Jia D, Fu M, Ma F. The mitigation effects of exogenous melatonin on salinity-induced stress in Malus hupehensis. J Pineal Res. 2012:53:298-306.

31. Liu N, Gong B, Jin Z, Wang X, Wei M, Yang F, Li Y, Shi Q. Sodic alkaline stress mitigation by exogenous melatonin in tomato needs nitric oxide as a downstream signal. J Plant Physiol. 2015;186-187:68-77.

32. Wen D, Gong B, Sun S, Liu S, Wang X, Yang F, Li Y, Shi Q. Promoting Roles of Melatonin in Adventitious Root Development of Solanum lycopersicum $L$ by Regulating Auxin and Nitric Oxide Signaling Frontiers in Plant Science, $2016 ; 7,718$.

33. Zhang $N$, Zhang HJ, Zhao B, Sun QQ, Cao YY, Li R, Wu XX, Weeda S, Li L, Ren $\mathrm{S}$, et al. The RNA-seq approach to discriminate gene expression profiles in response to melatonin on cucumber lateral root formation. J Pineal Res. 2014;56:39-50

34. Wang LY, Liu JL, Wang WX, Sun Y. Exogenous melatonin improves growth and photosynthetic capacity of cucumber under salinity-induced stress. Photosynthetica. 2016;54(1):19-27. 
35. Yan Y, Jing X, Tang H, Li X, Gong B, Shi Q. Using transcriptome to discover a novel melatonin-induced sodic alkaline stress resistant pathway in Solanum lycopersicum L. Plant Cell Physiol. 2019;60:2051-64.

36. Wang P, Yin L, Liang D, Li C, Ma F, Yue Z. Delayed senescence of apple leaves by exogenous melatonin treatment: toward regulating the ascorbate-glutathione cycle. J Pineal Res. 2012;53:11-20.

37. Bajwa VS, Shukla MR, Sherif SM, Murch SJ, Saxena PK. Role of melatonin in alleviating cold stress in Arabidopsis thaliana. J Pineal Res. 2014;56:238-45.

38. Gilroy S, Białasek M, Suzuki N, Górecka M, Devireddy AR, Karpi'nski S, Mittler R. ROS, calcium, and electric signals: key mediators of rapid systemic signaling in plants. Plant Physiol. 2016;171:1606-15.

39. Gong B, Yan Y, Wen D, Shi Q. Hydrogen peroxide produced by NADPH oxidase:a novel downstream signaling pathway in melatonin-induced stress toelrance in Solanum lycopersicum. Physiol Plant. 2017;160:396-409.

40. Lerner AB, Case JD, Takahashi Y, Lee TH, Mori W. Isolation of melatonin, a pineal factor that lightens melanocytes. J Am Chem Soc. 1958;80:2587.

41. Li, J., Zhao, C., Zhang, M., Yuan, F., Chen, M. Exogenous melatonin improves seed germination in Limonium bicolor under salt stress. Plant Signaling Behavior, 2019; e1659705.

42. Fan J, Xie Y, Zhang Z, Chen L. Melatonin: a multifunctional factor in plants. Int J Mol Sci. 2018;19:1528.

43. Yuan F, Chen M, Yang J, Song J, Wang BS. The optimal dosage of $60 \mathrm{co}$ gamma irradiation for obtaining salt gland mutants of exo-recretohalophyte Limonium bicolor (Bunge) O. Kuntze Pak J Bot 2015; 47:71-76.

44. Leng BY, Yuan F, Dong XX, Wang J, Wang BS. Distributionpattern and salt excretion rate of salt glands in two recretohalophyte species of Limonium (Plumbaginaceae). S Afr J Bot. 2018;115:74-80. https//doi.org/10.1016/j.sajb.2018.01.002.

45. Munns R, Tester M. Mechanisms of salinity tolerance. Annu Rev Plant Biol. 2008;59:651-81.

46. Sun ZB, Qi XY, Wang ZL, Li PH, Wu CX, Zhang H, Zhao YX. Overexpression of TsGOLS2, a galactinol synthase, in Arabidopsis thaliana enhances tolerance to high salinity and osmotic stresses. Plant Physiol Biochem. 2013; 69:82-9.

47. Shao Q, Han N, Ding TL, Zhou F, Wang BS. SsHKT1; 1 is a potassium transporter of the $C_{3}$ halophyte Suaeda salsa that is involved in salt tolerance. Funct Plant Biol. 2014;41 (8):790-802.

48. Han GL, Wang MJ, Yuan F, Sui N, Song J, Wang BS. The CCCH zinc finger protein gene AtZFP1 improves salt resistance in Arabidopsis thaliana. Plant Mol Biol. 2014;86:237-53.

49. Han GL, Yuan F, Guo JR, Zhang Y, Sui N, Wang BS. AtSIZ1 improves salt tolerance by maintaining ionic homeostasis and osmotic balance in Arabidopsis. Plant Sci. 2019;285:55-67.

50. Gong Z, Xiong L, Shi H, Yang S, Herrera-Estrella L, Xu G, Chao D-Y, Li J, Wang P, Qin F, Li B, Ding Y, Shi Y, Wang Y, Yang Y, Guo Y, Zhu J-K. Plant abiotic stress response and nutrient use efficiency. Sci China Life Sci. 2020; 63. https://doi.org/10.1007/s11427-020-1683-x.

51. Jiang C, Cui Q, Feng K, Xu D, Li C, Zheng Q. Melatonin improves antioxidant capacity and ion homeostasis and enhances salt tolerance in maize seedlings. Acta Physiol Plant. 2016;38:82.

52. Zhao G, Zhao Y, Yu X, Kiprotich F, Han H, Guan R, Wang R, Shen W. Nitric oxide is required for melatonin-enhanced tolerance against salinity stress in rapeseed (Brassica napus L.) seedlings. Int. J. Mol. Sci. 2018; 19, 1912.

53. Sun S, Wen D, Yang W, et al. Overexpression of Caffeic Acid O -Methyltransferase 1 ( COMT1 ) Increases Melatonin Level and Salt Stress Tolerance in Tomato Plant. J Plant Growth Regul, 2019; 1-15.

54. Lin J, Li JP, Yuan F, Yang Z, Wang BS, Chen M. Transcriptome profiling of genes involved in photosynthesis in Elaeagnus angustifolia $\mathrm{L}$ under salt stress Photosynthetica, 2018; 56, 998-1009.

55. Kuwabara A, Nagata T. Cellular basis of developmental plasticity observed in heterophyllous leaf formation of Ludwigia arcuate (Onagraceae). Planta. 2006:224:761-70

56. Yuan F, Chen M, Yang J, Ling BY, Wang BS. A system for the transformation and regeneration of the recretohalophyte Limonium bicolor. In Vitro Cell Dev-PI. 2014:50:610-7.

57. Gao W, Zhang Y, Feng Z, Bai Q, He J, Wang Y. Effects of melatonin on antioxidant capacity in naked oat seedlings under drought stress. Molecules. 2018:23:1580.

\section{Publisher's Note}

Springer Nature remains neutral with regard to jurisdictional claims in published maps and institutional affiliations.

\section{Ready to submit your research? Choose BMC and benefit from:}

- fast, convenient online submission

- thorough peer review by experienced researchers in your field

- rapid publication on acceptance

- support for research data, including large and complex data types

- gold Open Access which fosters wider collaboration and increased citations

- maximum visibility for your research: over $100 \mathrm{M}$ website views per year

At BMC, research is always in progress.

Learn more biomedcentral.com/submissions 